\title{
MEDICAL ECONOMICS: LEGALIZE ORGAN MARKETS
}

\author{
Justin Callais ${ }^{1}$; Walter E. Block ${ }^{2}$ \\ ${ }^{1}$ Joseph A. Butt, S.J. College of Business, Loyola University New Orleans, 6363 St. Charles Avenue, \\ New Orleans, LA 70118 \\ ${ }^{2}$ Harold E. Wirth Eminent Scholar Endowed Chair and Professor of Economics, Joseph A. Butt, S.J. College of \\ Business, Loyola University New Orleans, 6363 St. Charles Avenue, \\ Box 15, Miller Hall 318, New Orleans, LA 70118 \\ 1jtcallai@loyno.edu; ${ }^{2}$ wblock@loyno.edu
}

\begin{abstract}
The article argued to the contrary that at least insofar as organ transplants were concerned, this general assumption lied 180 degrees away from the truth. The first reaction of most concerned people, at the prospect of buying and selling human body parts, was one of revulsion. And, yet, this was the tried and true means that used for supplying more pedestrian goods and services. The article was the economic principles responsible for adequately making available to us such as items such as apples, shoes, and gardening services were the best ones in this case as well. The method was to argue that the institutions responsible for most goods and services in the economy that the last best hope for solving the problems that faced transplants of human body parts. The researchers consulted google scholar and mises.org and generated in this manner and cited almost a dozen publications which discussed the relevant subject matter and commented on several of them. It finds that Pro-organ sellers have a long way to go, but with determination and logic, one day the world will find a place for organs in the free-markets. And, then, many lives will be saved.
\end{abstract}

Keywords: medical economics, organ markets

\section{INTRODUCTION}

Organ selling is an issue that is widely discussed among economists and political philosophers, but it is not legal (with the exception of one country). Many people find organ selling to be immoral, others claim it is exploitative, and virtually all say there is no chance the practice can ever be legalized, at least not in any civilized country. An objection voiced by many is that the poor would not be able to afford organs, and so would be left out. Some may even just find the topic too controversial even to discuss. This topic is without a doubt not considered mainstream, but it can be deliberated upon.

As of 2016 in the United States, selling human organs is punishable by law, but it has not always been this way. In 1983, H. Barry Jacobs, a Virginian physician, saw a shortage in organs as well as a growing demand for transplants and decided to do what any savvy entrepreneur would undertake; start a company to fulfill this need (Sullivan, 1983). He planned to purchase human organs from willing participants for about $\$ 10,000$ with an additional $\$ 2.000-\$ 5.000$ commission fee for Dr. Jacobs and then sell them to those in need who were willing and able to buy them. It did not take very long before Congress shut this idea down, with then Representative Al Gore in the forefront of passing the National Organ Transplant Act of 1984, effectively banning the sale of human organs (Meckler, 2007). This bill has led to the laws in place today.

In the view of many commentators, while the marketplace can be relied upon to supply a plethora of goods and services, an exception must be made for medical care in this regard. In this field, 
matters are too important and too complex to be left to the unstructured, profit-seeking, callous system of laissez-faire capitalism. The present research is an attempt to make a case for free enterprise, even for this industry. Researchers maintain that an unhampered market in used bodily organs is the sine qua non of good health and that the present system, in which markets in this commodity are prohibited, does not well-serve the public. The researchers thus call for the break-up of this institution.

\section{METHODS}

For the references, the researchers consulted google scholar and mises.org. The researchers generated in this manner and cited almost a dozen publications which discussed the relevant subject matter and commented on several of them.

\section{RESULTS AND DISCUSSIONS}

As surprising as this may sound, the only country in the entire world able to boast of a sliver of free-market policies regarding the sale of organs is Iran. In mentioning this case, US is of course at least implicitly extrapolating from the Iranian situation to that of the US. People, of course, should all be aware of the dangers of doing, so that gives the significant economic differences between the two countries. However, there are some benefits too. Otherwise, the researchers would not be justified in even referring to this case in point. In their system, the government offers a compensation of a little over \$1.000 in addition to insurance for a year after the surgery. After the purchase, the government then sells the organ to a needy buyer, whether through a payment from him or a charity with a purchase price ranging between $\$ 2.300$ and $\$ 4.500$ (Dubner, 2008). However, there is one a similarity between practice in Iran and the United States. Both are centrally controlled, but in the latter, there is no monetary exchange involved. People must obtain permission from the doctor who in turn refers to a transplant center. There that people will be evaluated based on considerations such as age, blood type, waiting time, proximity to the organ, and the urgency of the situation (Organ Type and Waiting Time). The results are placed into a database controlled by the United Network for Organ Sharing, and this organization coordinates with regional organ procurement organizations (OPOs) that checks with the transplant recipients in their area when an organ becomes available. If there is no one in that region which matches this specific organ, then the OPO finds a suitor in a close-by region until they find someone appropriate (Hainer, 2009). In fact, over $80 \%$ of all organs are donated and received in the same geographical area (The Gift of a Lifetaime, 2004).

This process is ineffective and causes many unnecessary deaths. A system with over 121.678 people on the waitlist to receive a lifesaving transplant list; a system that witnesses 22 people die every day waiting for that organ is a system that is completely broken. 100.791 of those people are waiting for kidneys (National Kidney Foundation, 2014). Wilkinson (2016) argues that the actual numbers of persons who need transplants are not effectively represented by such waiting lists. On average, people are stuck waiting for a kidney for around five years with 13 people are dying daily on the waitlist (National Kidney Foundation, 2014). As a country are adding 52.560 people to the waitlist every year, while only giving transplants to around 23.214 patients (American Transplant Foundation, 2016). 650,000 transplants over 28 years yield the calculation 23.214 per year. A price control of zero dollars on organs is killing way too many people daily, and free market policies are the most efficient way to fix this (Smith, 1776; Hazlitt, 1946).

In sharp contrast in Iran, 1.400 people per year or $0,0018 \%$ of the population sell an organ to their fellow citizens. If the United States has a free market policy using the same percentage of the 
population, it would have close to 575.000 paid organ donors. The 575,000 number uses the most recent US Population calculations of 318,9 million. This would lead to a surplus of around 453.322 organs. The abundance of organs would lower the price, when the supply increases (as is the case of a surplus of over 400.000 bodily parts), the price falls. This makes it more affordable for people to purchase the good. It makes them more affordable to poorer people, the main concern of those who support the status quo. Not only does this make sense economically, but politically as well. In the most basic free enterprise society, items can be sold and bought in a voluntary exchange. No matter what the economic implications are, the law should allow for consenting adults to make contractual decisions freely. In this case, it just so happens that economically it also makes sense; it will save precious human lives.

There are many criticisms of a free-market in organ selling, such as a class warfare struggle between the rich and the poor. For the general case that against the commodification or the alienability or selling is pretty much anything (see Radin, 1987) and for a refutation see in Block (1999). Critics claim that the rich are the only ones who can afford to buy the organs. Therefore economic freedom will kill off many poor people. Strong critics of legal free markets in this commodity include Wilkinson (2003); Etzioni (n.d); Scheper-Hughes (2005); Caplan (2013); Bramstedt (2014). Supporters of legalization are also very adamant in presenting their case are Anderson (2003); Anderson and Barnett (1999); Barnett (1999); Barnett (1988); Barnett, Saliba, \& Walker (2001); Barnett and Saliba, (2004); Beard, Jackson, \& Kaserman (2007-2008); Block et al. (1999-2000); Block (1987, 1988A,1988B); Carey (2002); Cherry (1999), Clay \& Block (2002). Additionally, the poor people would be the ones who would need to sell their body parts for money, since the rich people would not need the money. As Bramstedt (2014) mentions, "payments for organs equates to price tags for them, and who gets to put a price on life?"

Along with the clash between the people of different economic status, many believe it unethical to sell body parts, since we are all equal in value. Theologians say that since the body is a gift from God, it does not belong to humans and therefore the parts of the body cannot sell for monetary enrichment (Caplan, 2013). This claim is based on the philosophy that belong to a greater being and that $\mathrm{He}$ is the true owner of the body and soul. Unfortunately, these critiques do not offer any solution to the problem of the shortage of organs.

In the United States, People must sign up to be organ donors, which deters many people. This could be for many reasons, including not knowing how to sign up, being unaware that someone can be an organ donor, laziness, or in the most extreme cases, reservations about hospitals not saving their lives so that they can foster your organs. Some critics claim the system in Spain is the fairest and most effective. The Spanish government nudges (Sunstein \& Thaler, 2003; 2008), people by automatically signing them up to be organ donors and they must apply to opt-out; as a result, few actually refusing (Rizzo \& Whitman, 2003; Whitman \& Rizzo, 2007). This case is an extremely strong case, as Spain has one of the highest donation results in the world (Clark and Clark, 2013).

Another argument against organ buying and selling is the supposed selfishness of money. Many believe that this filthy lucre is inherently immoral and people are abusing its power in order to exploit others, particularly the poor. Rich people, under a free-market system, would be able to throw money at the poor in exchange for their body parts, degrading the human value of the poor person who is being manipulated.

Society must combat the claims that mainly the affluent would receive organs and thus demean the life of the poor. It must realize that this is already happening under the current system. For example, several factors presently allow the rich to receive organs faster and with greater probability than their poorer brethren; first, those with greater wealth are more likely to have better insurance which covers more of the cost of a transplant. The average liver transplant costs around $\$ 519.600$ (Hainer, 2009), while FlyMedi Guide (2015) places this at \$750.000. Second, transplant centers allow 
individuals to be tested at more than one location, which then gives patients a greater chance of matching a donor. This gives the rich yet another advantage, as they are more financially capable of flying around the country to be tested in different regions (Hainer, 2009). Third, the powers that be will only award organs to those in good health, who do not smoke. Again, the well-to-do have an advantage here "Wealthier is healthier" is a good summation of the relationship between these two variables.

Even though rich people will probably be better off under free enterprise as they already are in the current system - at least poor people will have greater chances to receive an organ as well. The affluent are better off under all real-world economic systems. Only under laissez-faire capitalism, the only way they can attain wealth is by enriching others. Every computer that Bill Gates sold was valued by the consumers at a greater rate than the price they paid; otherwise, they would not have made the purchase. It is only under socialism, or crony capitalism, that great riches can be garnered in the absence of reducing the poverty of others. Plus, in almost any case, the rich will be in a better position than the poor, especially when it comes to factors like healthcare. People will still donate organs for free, even though they can choose to be paid for it, for this frequently happens. According to Giving USA (2015), 8\% of the $\$ 358$ billion or $\$ 30.37$ billion in charitable donations in 2014 went towards health causes. People often donate goods that they could sell in the market, but instead, donate to charity. A free market for body organs could also actually help poor people lift themselves out of poverty. They would now have something additional to sell.

As the case for every illegal product, there is a black market. These are usually both more expensive and extremely dangerous. It is because of as barriers to entry are higher due to the risks of imprisonment, the supply is reduced. For example, marijuana's black market has an upcharge effect on the price and a negative effect on the safety of those involved. Legalizing a product destroys business for the black market, as in Colorado where in just one week, $\$ 5$ million is taken from illegal dealers and instead placed back into that state government's coffers (Clarke, 2014). For kidneys, the black market price is estimated to be around $\$ 160.000$, as compared to Iran, where the purchasing price is somewhere between \$2.300-4.500 (Dubner, 2008; Martinez, 2009). The black market kidney ranges from around 35-70 times more expensive than the Iranian costs. One can reasonably expect with the surplus of over 400.000 kidneys in the United States; the price would be even lower than the Iranian cost. As it can be seen, the free market policies lead to lower prices.

Also, many say that selling organs is unethical, but this is difficult to accept for a system that allows for more opportunities to receive organs rather than is responsible for thousands of unnecessary deaths. Is it more ethical that under prohibition "everyone involved in the organ transplant business is compensated - that includes hospitals, surgeons, nurses, and organ procurement workers, except the donor" (Williams, 2013). The researchers use this description purposefully because there are strong parallels between alcohol prohibition and the outlawry of markets in used body parts. Both are responsible for many deaths of innocent people. As Rabba (2015) mentions, "Either way, you're saving a life". People must realize what is truly important at the end of the day; saving lives. Now it should be asked the difference between being able to sell a kidney or one selling his or her eggs or sperm, respectively. It is their own body, and therefore should be their decision.

About Spain's opt-out program, in the researchers' view, the federal government has no right to order an adult about what they can or cannot do with their bodies; nor, even, to nudge them in any direction or other. One of the major aspects of a free society involves people being able to make decisions on their own accord, not based on what a state demands or nudges them to do. Governments have tried time and time to nudge people's behaviors to fit a culture that suits the government. For example, the Britain legislation changes the way corporate pension plans operate, and now employees are automatically enrolled unless they opt-out (The Economist, 2012). It is also profoundly undemocratic. If the average citizen is so stupid that he/she is in need of a nudge from his/her betters, 
he/she is too incompetent to be given access to the ballot box. Conversely, if he/she is allowed to vote, this demonstrates that he/she is competent enough not to be nudged.

One challenge offered is that the legalization of kidneys would cause a rise in people murdering each other in order to capture their organs. In fact, the exact opposite would happen; the incentives for such "body snatching" would decrease, not increase. Anything in life, when the reward for an act is reduced, people will see less of it, not more of it. With the legalization of organs, society could expect to see an increase in the supply, which would cause the price to fall. With this decrease, those who would consider murdering for organs would see much less of an incentive to do so.

Another point made by the opposing side is that society would be exploiting those less fortunate by immorally using the money. The best response to this is by asserting that money is not the only good available in the market, money is just the most commonly used well. What is the difference between someone selling a kidney for $\$ 5.000$ or one donating the kidney for free, but receiving $\$ 5.000$ worth of fame in the news? Fame is often as valuable of a good as money. One cannot claim that money is evil without also saying that fame and the ability to feel good about yourself is just as, if not eviler. One may argue that fame and feeling good about one's self is more evil than money because at least the money makers are being honest with themselves about what they are doing this for. On the other hand, it is too often that we see people who donate gloating in such a way that detracts from the actual donation. Why should the supposed evil of exchange intermediaries arise only in the case of human organs? Why, not, also, for more pedestrian goods and services such as apples and shoes, carwashing and baby-sitting? If money is the root of all evil, it is more than passing curious that its deleterious effects should be constrained to merely such a few items, such as used body parts.

One last critique is the poor and ignorant will sell their bodily organs frivolously. For example, Andre and Velasquez (1988) opine that allowing organs to be bought and sold would lead to what one critic called the plundering of peasants' parts for profits; the exploitation of the poor and ignorant, especially in impoverished third-world countries. People living in extreme poverty are often desperate and ill-informed. Profit-seekers would take advantage of this, obtaining consent" from those who feel compelled by necessity to sell their organs, and who may not have a clear idea of the consequences of what they were doing. Such a scheme would encourage the most vulnerable in society to treat themselves as commodities and allow others to violate their rights for commercial gain (see Borna, 1987; Moniruzzaman, 2012; Henion and Moniruzzaman, 2012).

\section{CONCLUSIONS}

Markets in used body parts are the last best hope for saving lives. Organ selling will always be an extremely controversial topic. Even those who can understand the economic basis for legalization will have trouble finding ways to accept it from a moral point of view. Those in opposition need to understand that the moral aspect of organ selling as well, especially when it comes to the rationale to want all parties involved should be paid for their service, not just the hospital and its employees. Once opponents can truly understand the economic and ethical arguments for organ selling, the legalization process can start. Pro-organ sellers have a long way to go, but with determination and logic, one day the world will find a place for organs in the free-markets. And, then, many lives will be saved. 


\section{REFERENCES}

Anderson, W. L., \& Barnett, A. (1999). Waiting for Transplants. The Free Market, 17(4). Retrieved from http://mises.org/freemarket_detail.aspx?control=29

Anderson, W. L. (2003). Communitarianism and Commodification. Retrieved from http://mises.org/story/1174.

Andre, C., \& Velasquez, M. (1988). Kidneys for sale. Issues in Ethics, 1(2). Retrieved from https://www.scu.edu/ethics/focus-areas/bioethics/resources/kidneys-for-sale/.

American Transplant Foundation. (2016). Facts and Myths. Retrieved on April 6 ${ }^{\text {th }}, 2017$ from http://www.americantransplantfoundation.org/about-transplant/facts-and-myths/.

Barnett, A. W. (1988). The Market for Used Human Body Parts. The Free Market, 6(2). Retrived from http://mises.org/daily/4231.

Barnett, A. W., \& Anderson, W. L. (1999). Die Waiting. Retrieved from https://mises.org/library/diewaiting.

Barnett, A., W., Saliba, M., \& Walker, D. (2001). A Free Market in Kidneys: Efficient and Equitable. The Independent Review, 5(3), 373-385. Retrieved from http://www.independent.org/pdf/tir/tir_05_3_barnett.pdf.

Barnett, A. W., \& Saliba, M. (2004). A Free Market for Kidneys: Options, Futures, Forward, and Spot. Managerial Finance, 30(5), 38-56.

Beard, T. R., Jackson, J. D., \& Kaserman, D. L. (2007-2008). The Failure of U.S. Organ Procurement Policy. Regulation, 30(4). Retrieved from http://papers.ssrn.com/sol3/papers.cfm?abstract_id=1092920.

Block, W. E. (1987). A Free Market in Kidneys? The Freeman Ideas on Liberty, 308. Retrieved from http://www.fee.org/vnews.php?nid=1802.

Block, W. E. (1988A). Caveat Emptor. The Freeman Ideas on Liberty, 180-181. Retrieved from http://www.fee.org/vnews.php?nid=1903.

Block, W. E. (1988B). The Case for a Free Market in Body Parts. In Llewellyn Rockwell (ed.), Essays in the Economics of Liberty: The Free Market Reader (pp. 65-70, 195-199, 266-272). California: The Ludwig von Mises Institute. Rerieved from http://www.mises.org/freemarket_detail.asp?control=476.

Block, W. E. (1999). Market Inalienability Once Again: Reply to Radin. Thomas Jefferson Law Journal, 22(1), 37-88. Retrieved from http://papers.ssrn.com/sol3/papers.cfm?abstract_id=1889458.

Block, W. E., Whitehead, R., Johnson, C., Davidson, M., White, A., \& Chandler, S. (1999-2000). Human Organ Transplantation: Economic and Legal Issues. Quinnipiac College School of Law Health Journal, 3, 87-110. Retrieved from http://141.164.133.3/faculty/Block/Articles\%20for\%20web/Human\%20Oragn; http://www.walterblock.com/publications/human_organ_transplantation.pdf. 
Borna, S. (1987). Morality and Marketing Human Organs. Journal of Business Ethics, 6(1), 37-44.

Bramstedt, K. (2014, August 21 ${ }^{\text {st }}$ ). Buying and Selling Organs Would Create an Economic Class War. New York Times. Retrieved on May $12^{\text {th }}$, 2016 from http://www.nytimes.com/roomfordebate/2014/08/21/how-much-for-a-kidney/buying-andselling-organs-would-create-an-economic-class-war.

Caplan, A. (2013, October $\left.24^{\text {th }}\right)$. Why Selling Kidneys Still Won't Work. NBC News. Retrieved on April $6^{\text {th }}, 2016$ from http://www.nbcnews.com/health/opinion-why-selling-kidneys-still-wontwork-8C11459943.

Carey, D. (2002). Let the Market Save Lives. Mises Daily. Retrieved from http://mises.org/daily/898.

Cherry, Mark J. (1999). Persons and Their Bodies: Rights, Responsibilities, and the Sale of Organs. Netherlands: Kluwer Academic Publishers.

Clark, M., \& Clark, W. T. (2013). Selling Your Organs: Should It Be Legal? Do You Own Yourself? Forbes Magazine. Retrieved on April $6^{\text {th }}$, 2016 from http://www.forbes.com/sites/marciaclark/2013/06/13/selling-your-organs-should-it-be-legaldo-you-own-yourself/\#74a2b2d395db.

Clarke, T. H. (2014). Colorado's Marijuana Sales Kept $\$ 5$ Million from Black Market in 1 Week. The Daily Chronic. Retrieved on May $19^{\text {th }}, 2016$ from http://www.thedailychronic.net/2014/27122/colorados-marijuana-sales-kept-5-million-blackmarket-1-week/.

Clay, M., \& Block, E. W. (2002). A Free Market for Human Organs. The Journal of Social, Political and Economic Studies, 27(2), 227-236. Retrieved from http://www.walterblock.com/publications/market_human_organs.pdf; http://www.jspes.org/summer2002_clay.html.

Dubner, S. J. (2008). Human Organs for Sale, Legally, in ... Which Country? Retrieved on April $6^{\text {th }}$, 2016 from http://freakonomics.com/2008/04/29/human-organs-for-sale-legally-in-whichcountry/.

Etzioni, A. (n.d.). Organ Donation: A Communitarian Approach. Retrieved from https://www.gwu.edu/ ccps/Organ_Donation.pdf.

FlyMedi Guide. (2015). How Much Does a Liver Transplant Cost? Retrieved from http://www.flymedi.com/guide/how-much-does-a-liver-transplant-cost/.

Giving USA. (2015). Giving USA: Americans Donated an Estimated $\$ 358.38$ Billion to Charity in 2014; Highest Total in Report's 60-year History. Retrieved May 19 ${ }^{\text {th }}$, 2016 from http://givingusa.org/giving-usa-2015-press-release-giving-usa-americans-donated-anestimated-358-38-billion-to-charity-in-2014-highest-total-in-reports-60-year-history/

Hainer, R. (2009). Did Steve Jobs' Money Buy Him a Faster Liver Transplant? Retrieved from April $6^{\text {th }} \quad 2016 \quad$ from http://www.cnn.com/2009/HEALTH/06/24/liver.transplant.priority.lists/index.html?iref=24ho urs; http://www.cnn.com/2009/HEALTH/06/24/liver.transplant.priority.lists/. 
Hazlitt, H. (1946). Economics in One Lesson. Auburn, AL: Mises Institute. Retrieved from http://mises.org/books/economics_in_one_lesson_hazlitt.pdf

Henion, A., \& Moniruzzaman, M. (2012). Growing Market for Human Organs Exploits Poor. Retrieved from http://msutoday.msu.edu/news/2012/growing-market-for-human-organsexploits-poor/.

Martinez, E. (2009). Black Market Kidneys, \$160,000 a Pop. CBSNews. Retrieved on April $6^{\text {th }}, 2016$ from http://www.cbsnews.com/news/black-market-kidneys-160000-a-pop/.

Meckler, L. (2007). Kidney Shortage Inspires A Radical Idea: Organ Sales. Retrieved on April $6^{\text {th }}$, 2016 from http://www.wsj.com/articles/SB1 19490273908090431.

Moniruzzaman, M. (2012). Living Cadavers' in Bangladesh: Bioviolence in the Human Organ Bazaar. Medical Anthropology Quarterly, 26(1), 69-91. Retrieved from http://news.msu.edu/media/documents/2012/03/73a832b2-0893-4837-99fb9ab6d10db302.pdf.

National Kidney Foundation. (2014). Organ Donation and Transplantation Statistics. Retrieved on April $6^{\text {th }}, 2016$ from https://www.kidney.org/news/newsroom/factsheets/Organ-Donation-andTransplantation-Stats

Rabba, H. (2015). On Organ Donation, Organ Sales, and Hypocrisy. Retrieved on April 6 ${ }^{\text {th }}, 2016$ from https://thejewishlibertarian.com/2015/06/22/on-organ-donation-organ-sales-andhypocrisy/.

Radin, M. J. (1987). Market-Inalienability. Harvard Law Review, 100(8), 1849-1937.

Rizzo, M. J., \& Whitman, G. (2003). The Camel's Nose is in the Tent: Rules, Theories and Slippery Slopes. UCLA Law Review, 51(2), 539-592.

Scheper-Hughes, N. (2005). The Ultimate Commodity. Retrieved from http://www.thelancet.com/journals/lancet/article/PIIS0140-6736(05)67550-2/abstract

Smith, A. (1776). The Wealth of Nations. New York: Modern Library.

Sullivan, W. (1983). Buying of kidneys of poor attacked. Retrieved from http://www.nytimes.com/1983/09/24/us/buying-of-kidneys-of-poor-attacked.html.

Sunstein, C. R., \& Thaler, R. H. (2003). Libertarian Paternalism Is Not An Oxymoron. Retrieved from http://papers.ssrn.com/sol3/papers.cfm?abstract_id=405940.

Sunstein, C. R., \& Thaler, R. H. (2008). Nudge: Improving Decisions About Health, Wealth, and Happiness. New Haven: Yale University Press.

The Gift of a Lifetime. (2004). The Organ Transplant Waiting List. Retrieved from http://www.organtransplants.org/understanding/unos/

The Economist (2012, March 24 ${ }^{\text {th }}$ ). Nudge Nudge, Think Think; The use of behavioural economics in public policy shows promise. The Economist Newspaper. Retrieved on May 16 ${ }^{\text {th }}, 2016$ from http://www.economist.com/node/21551032. 
Whitman, G., \& Rizzo, M. J. (2007). Paternalist Slopes, New York University Journal of Law and Liberty, 2(2007), 411-443.

Wilkinson, S. (2003). Bodies for sale: ethics and exploitation in the human body trade. New York: Routledge.

Wilkinson, T. M. (2016). Ethics and the Acquisition of Organs. UK: Oxford University Press.

Williams, W. (2013). Because There's No Free Market in Organs. Retrieved on April 6 ${ }^{\text {th }}, 2016$ from https://www.lewrockwell.com/2013/06/walter-e-williams/because-theres-no-free-market-inorgans/. 